University of Chicago Law School

Chicago Unbound

Journal Articles

Faculty Scholarship

1980

\title{
Lawmaking and Public Opinion Research: The President and Patrick Caddell
}

Hans Zeisel

Follow this and additional works at: https://chicagounbound.uchicago.edu/journal_articles

Part of the Law Commons

\section{Recommended Citation}

Hans Zeisel, "Lawmaking and Public Opinion Research: The President and Patrick Caddell," 1980 American Bar Foundation Research Journal 133 (1980).

This Article is brought to you for free and open access by the Faculty Scholarship at Chicago Unbound. It has been accepted for inclusion in Journal Articles by an authorized administrator of Chicago Unbound. For more information, please contact unbound@law.uchicago.edu. 


\section{Lawmaking and Public Opinion Research: The President and Patrick Caddell}

Hans Zeisel

The people's sense of what is good and right is both the ultimate source and the ultimate strength of the rules that govern a democratic society. If there is a major discrepancy between that sense and the rules, the rules and those who cling to them will eventually disappear.

Lawmakers, therefore, have a continuing interest in the opinions of their constituencies. That interest is heightened in election years when the lawmakers look for guidance as to what to say and what not to say, either generally or before special segments of the constituency.

Polls designed for these purposes are fairly simple. They ask the citizens about their concerns and fears, about their attitudes toward specific issues that may have arisen or could arise during the campaign. By assessing the salience of each concern and by relating its importance to the strength of the candidate among the various segments of the electorate, such simple surveys provide important help.

The task of the pollster becomes more difficult when guidance is required not for oratory but for action. For that more serious purpose, the off-the-top-of-the-head reaction of the citizenry does not suffice and may even mislead. What is required is the citizen's considered reaction, which in turn requires his fuller understanding of the issue and its consequences. If the issue is complex, the task of the pollster becomes correspondingly complex. This complexity, however, can be reduced by sharpening the issue on which the policy maker wants to hear public opinion.

Generally, it is not easy to study the role opinion polls play in policy making, because most opinion polls are privately conducted; in any event, little is known about what use has been made of them. In one recent instance, however, I happened to come across both the poll and the use that was made of it. And since the instance was an important

Hans Zeisel is Professor Emeritus of Law and Sociology, University of Chicago; Research Associate, Center for Studies in Criminal Justice, University of Chicago; and Consultant, American Bar Foundation. 
one-President Carter's Let-Us-Restore-Confidence speech of July 15, 1979-it will allow us a broader perspective on both the pitfalls and the advantages of using opinion polls in the affairs of government. That particular poll, it turns out, was of very doubtful quality, and the President's reliance on it difficult to understand.

In that July 15 speech, we might recall, the President, after quoting some of the good and bad news he had received in his mail, proceeded to tell the nation his plans for resolving the energy crisis that had suddenly become manifest through the ubiquitous gas lines. The President told his audience that it was our "excessive dependence on OPEC" that had caused these lines, and, therefore, he continued, "I am announcing tonight that for 1979 and 1980 I will forbid the entry into this country of one drop of foreign oil more" than we had imported in 1977.'

It seemed a puzzling way to begin. At the price the government had set, demand for gas had outstripped supply. In such a situation only two cures are available: reduce the demand or increase the supply. ${ }^{2}$ Setting a ceiling on imports, that is, reducing the supply without reducing the demand, could not possibly effect a cure; if anything, it would aggravate the situation.

Increasing the supply of domestic energy is a long-range proposition. In the short run only demand reduction can cure the problem. And demand can be reduced in only three ways, one of which, voluntary conservation, had already been tried and had failed at the time of the President's speech. So there remained only two ways of eliminating the gas lines: rationing and price increase.

Since all this is elementary economics, the President must have known it. Why, then, did he talk about setting import limits which, however necessary, could never help in removing the gas lines?

It is on this point that the polls of the President's advisor on public opinion, Patrick Caddell, as reported in his Cambridge Report for the Third Quarter of 1978, shed some light. ${ }^{3}$ The polls seemed to show that cutting oil imports was all that the majority of the American people wanted. However, careful reading of these polls suggests that they showed nothing of the kind.

The questions on oil imports which Caddell asked in that poll began innocently enough with:

1. New York Times, July 16, 1979, at A-10, col. 5.

2. The subject of this essay is polling the population for its views, not the pricing of gas at the pump. For that reason I have not hesitated to state the economic principles underlying that pricing in what some may regard as overly simplified. Simplified or not, the formulation is essentially correct.

3. Caddell's Cambridge Report is sent to subscribers. Compare Elizabeth Drew's piece in the April 27, 1979, issue of the New Yorker: Reporter at Large, Phase: In Search of a Definition. 
Q. 12-A: Would you favor or oppose reducing oil imports?

Sixty-three percent of the interviewees favored a reduction. This group was then asked a follow-up question.

Q. 12-B: How would you reduce oil imports?

Here are the answers as recorded in Caddell's Cambridge Report:

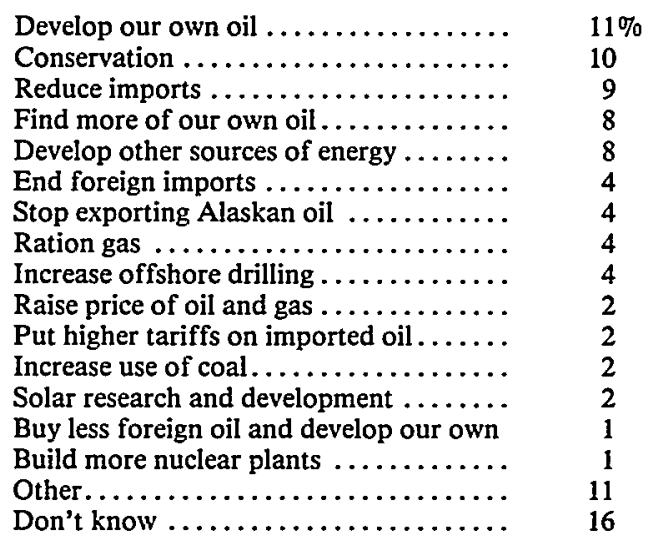

Before considering the implications of these answers, we should note the disorderly way in which they were reported. They should have been reported in a more orderly fashion, such as the following:

1. Reduce consumption

$\begin{array}{lc}\text { Conservation } \ldots \ldots \ldots \ldots \ldots \ldots \ldots \ldots & 10 \% \\ \text { Ration gas } \ldots \ldots \ldots \ldots \ldots \ldots \ldots & 4 \ldots \ldots \ldots \\ \text { Raise price of oil and gas } \ldots \ldots \ldots \ldots \ldots & 2 \\ \text { Raise oil tariffs } \ldots \ldots \ldots \ldots \ldots \ldots \ldots & 2\end{array}$

2. Develop domestic energy sources ............. (41\%)

a) Oil $\ldots \ldots \ldots \ldots \ldots \ldots \ldots \ldots \ldots \ldots \ldots \ldots(28 \%)$

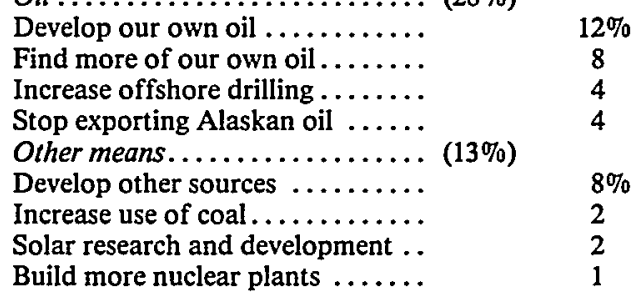

3. Don't know

Develop our own oil

Find more of our own oil.........

Increase of fshore drilling .........

Stop exporting Alaskan oil ......

4. Tautologies (no real answers)

Reduce imports ...

Also, the interviewers should not have accepted tautological answers. They should have asked again, with shifted emphasis:

But how should we reduce (end) imports? 
In such an ordered table, the 11 percent "other" answers would have probably found a less anonymous place among one or more of these subcategories.

The next question is the one that provoked the response that appears to have moved the President to announce "setting import limits" as the first step of his energy program.

Q. 12-C: Most people say that the only two ways to reduce oil imports are either by simply putting a set limit on the amount that could be imported, which would probably require some kind of rationing, or by sharply increased prices-such as $\$ 1.50$ per gallon of gasoline-to reduce the demand. If one or the other of these had to be done, which would you prefer?

Caddell would probably explain this question sequence by pointing out that question 12-C narrows the issue by asking the interviewees to choose between two of the many solutions they had been encouraged to propose by the preceding question. The narrowing seems rather drastic, however, when only 6 percent of all respondents to question 12-B had proposed either "rationing" or "price increases" as remedies. The smallness of these responses is the result of sloppy questioning. In none of the three questions are the interviewees warned to distinguish between remedies that, if adopted, would immediately have the desired effect of reducing consumption-such as price increases or rationing or voluntary conservation-and remedies that, if adopted, could become effective only after a substantial period of time-such as the development of domestic energy sources. At the very least the crucial question 12-C should have explained that the choice here was between two solutions designed to have an immediate effect.

Had questions 12-A and 12-B also been asked separately for the two issues-"What solution do you favor for the immediate future in which we cannot count on major increases in domestic supply?" and "What solutions do you favor in the long run?"-rationing and raised prices would have received a much greater share than the puny $4+2=6$ percent votes they actually generated. And questions $12-\mathrm{A}$ and $12-\mathrm{B}$ would then have served as a correct introduction to question $12-\mathrm{C}$.

Before reporting the answers obtained to question 12-C, we must look at its logical structure and also at the way in which that structure was presented to the interviewees. The structure consists of three elements: It is assumed that there must be a reduction of oil imports, and this can be effected in only two ways: through reducing the demand for oil by rationing, or through reducing the demand for oil by increasing its price. If oil imports were reduced without either rationing or increasing prices, the 
gap between supply and demand, which led to the gas lines, would reemerge until such remote time as domestic energy production could eliminate the gap. Thus, if there must be a reduction in oil imports, the choice to the consumer is only between rationing and a price increase.

So much for the question's logical structure. Its wording, however, fails to reflect this logic. The interviewee is not presented with the alternative of rationing versus price increase (which is the alternative if we must "reduce oil imports") but rather with the alternative of

(a) simply putting a set limit on the amount of oil that could be imported, or

(b) sharply increased prices-such as $\$ 1.50$ per gallon of gasoline

The real alternative to the price increase-rationing-is added in a deliberately tentative way at the end of (a) as a sort of afterthought: "which would probably require some kind of rationing . . . " This is a classic example of what pollsters call a loaded question. Note:

1. The main alternative is put to the interviewee as being a choice between "simply" setting oil import limits and increasing the price of gasoline-not between rationing and price increase; note the "simply."

2. The rationing alternative is hidden as a probable, not an inevitable, by-product of setting import limits; its threat is further diluted by calling it "some kind" of rationing.

3. The price increase alternative, on the other hand, is emphasized in three ways: first, by making it concrete- "such as $\$ 1.50$ per gallon of gasoline"; second, by calling it a sharp increase; and third, by putting this alternative at the end of a long question, a position that will invariably be better remembered by the understandably tired interviewee, whose attention span by that time must have been greatly strained. This was, by actual count, the fourteenth question, after such involved questions as the following:

Q. 9: One argument on the other side is that the law currently requires that cargo, including oil, that is shipped between two American ports-including Alaska and California-be carried on an American flagship with American seamen. Oil shipped between America and Japan could be carried on international ships. Some unions and shipping firms argue that it would be bad for America if the extra shipping jobs and ships were lost to foreign competition. Hearing this argument, would you favor or oppose shipping the oil to Japan?

On the basis of the analysis of question 12-C, it is easy to foresee what the answers of the 1,523 interviewees would be. Offered the choice be- 
tween no price increase and "probably. . . some kind of rationing" on the one hand and "sharp price increase to $\$ 1.50$ " on the other, the choice was foreordained. Only a small minority voted for the price increase:

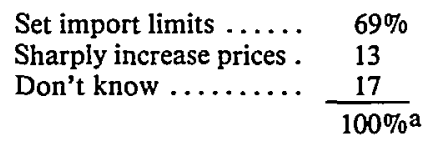

aTotal does not add to $100 \%$ due to rounding.

Caddell here labels correctly the alternatives from which the interviewees had to choose: "sharply increase prices" and "set import limits." Of the true alternatives-price increase versus rationing-Caddell takes no notice, nor, of course, did the interviewees who were induced by the loaded wording of the question to overlook it.

Thus, the votes in Caddell's poll were manipulated and, therefore, irrelevant and misleading. Yet the President clearly followed their guidance. He emphasized the decision to curtail imports, disregarded the time dimension, and mentioned price increase and rationing-the unpleasant but unavoidable short-run alternatives-only briefly and only by indirection:

This [program] will permit you to build conservation into your homes and your lives at a cost you can afford. I ask Congress to give me authority for mandatory conservation and for standby gasoline rationing [emphasis added]. ${ }^{4}$

It is perhaps not quite fair to blame only Caddell's misleading poll for the President's policy decision. The President could have told his pollster: "In the short run there are only two ways of alleviating the crisis-rationing or price increases. Find out what the people prefer. And to make the choice fair, make them understand that the price increase would be accompanied by some reimbursement for essential driving, especially for those in the lower income brackets." He probably did not do this. He perhaps aimed at a reenactment of his first primaries and his first election. Prior to a first election, poll questions are relatively simple. After a term of office, when reelection is the issue, the questions to which the answers are needed become more complicated.

But how can one ask in a poll for intelligent answers to such a complicated issue as the energy problem? How can one insure that the interviewees are aware of all the implications of what they vote for or against? Could these interviewees, for instance, really know what "rationing", time being at least, the President is pursuing the other route-increasing the price of gasoline. 
means when about two-thirds of the present population of the United States have never experienced any rationing? Will not the interviewees who are old enough to remember wartime rationing have a different conception of rationing? The question of how to make the implications of complex questions understood is fundamental and not easy to answer.

One could think of a new method to clarify the implications prior to asking the poll questions. Suppose the government, or one of its agencies, with the help of the National Academy of Sciences preempted or bought 6 or 10 or 12 hours of prime television time. Prepare a program that gives as much information on the issue or issues as can reasonably be absorbed; present that information fairly, not only by having adversaries talk but also by making use of all the magic of a pictorial and animated presentation, aided by commentary. Distinguish between undisputed and disputed facts, give their range of uncertainty, and allow for conflicting positions to appear. Distinguish between facts and value positions, and make clear the implications of accepting one or the other of these positions.

The entire presentation would be introduced by the announcement that this is the first segment of a national opinion poll that would be conducted by telephone on the following evening. The questions to be asked would be presented both at the beginning of each segment to which they refer and at the end of that segment so that the watching citizen would know what issue he should watch out for and eventually formulate an answer to.

The subsequent poll must.comprise a probability sample of the country's adult population, not the meaningless "write-in" sample that can never be more than a public relations stunt. The interview would ask all the poll questions and, in addition, would ascertain through appropriate test questions which, if any, segments of the program the respondent had watched. Such an effort might raise public opinion polling on complex issues to a new level.

Recently, social scientists from mainland China visited some of our universities. At the meeting we had at the University of Chicago, Kenneth Prewitt, now the president of the Social Science Research Council, explained to them the power of public opinion surveys in an unorthodox and interesting fashion: "It gives to both those who govern and those who are governed an inexpensive, direct channel to the people, unimpeded and unpolluted by intervening administrative layers." Up to now we have used this powerful instrument mainly for the simple, short-range political issues. The time may be ripe to use public opinion polls for loftier purposes and thus come closer to the potential role that public opinion research could play in the shaping of our policies. 
HeinOnline -- 1980 Am. B. Found. Res. J. 1401980 